Man and Nature

L'homme et la nature

\title{
Prophetic Discourse and the Voice of Protest: The Vindication of Anne Wentworth
}

\section{Vera J. Camden}

Volume 8, 1989

URI : https://id.erudit.org/iderudit/1012594ar

DOI : https://doi.org/10.7202/1012594ar

Aller au sommaire du numéro

Éditeur(s)

Canadian Society for Eighteenth-Century Studies / Société canadienne d'étude du dix-huitième siècle

ISSN

0824-3298 (imprimé)

1927-8810 (numérique)

Découvrir la revue

Citer cet article

Camden, V. J. (1989). Prophetic Discourse and the Voice of Protest: The

Vindication of Anne Wentworth. Man and Nature / L'homme et la nature, 8,

29-38. https://doi.org/10.7202/1012594ar

Copyright (c) Canadian Society for Eighteenth-Century Studies / Sociéte canadienne d'étude du dix-huitième siècle, 1989
Ce document est protégé par la loi sur le droit d'auteur. L'utilisation des services d'Érudit (y compris la reproduction) est assujettie à sa politique d'utilisation que vous pouvez consulter en ligne.

https://apropos.erudit.org/fr/usagers/politique-dutilisation/ 


\section{Prophetic Discourse and the Voice of Protest: The Vindication of Anne Wentworth}

C. E. Whiting, in his Studies in English Puritanism from the Restoration to the Revolution (1660-1688), introduces two Baptist women who have left narratives of their persecutions during the 1670's. He remarks that one, Agnes Beaumont of Bunyan's congregation, seems to have been innocent - as he puts it, 'a thoroughly good woman ... [while] A rather different case was that of Anne Wentworth. ${ }^{1}$ Anne Wentworth, it would seem, is not so 'good': Whiting's summary of her case is worth citing fully to discern wherein Anne's 'goodness' is found wanting:

She had been a Baptist but had left that sect, and suffered much at the hands of her former associates in consequence. She had also been ill-treated by her husband, and she had left him. She published a vindication of herself, in which she announced her willingness to return to him on condition that she should not be interfered with in her worship. Apparently she claimed a prophetic spirit, and she related how on the fifth day of the tenth month 1677 the Lord had awakened her in the night and made her sing unto Him a triumphant victorious song over her enemies. She appealed to the congregations of Anabaptists and their pastors, and asked if it was right of them to defame a neighbour in alehouses and coffeehouses; and she complained that she had been so defamed and abused for the past twenty four years, and had been proclaimed a heathen by the church. 'Let them prove her guilty of the things of which they accused her before the next Lord's New Year's Day, or trouble should come upon them [and the whole nation] from the Lord, and she would be able to rejoice when they had cause to mourn.'2

It would seem that Wentworth's 'difference' is her most unwomanly independence and her threat of revenge on her persecutors. Her religious vocation has not only inspired her rebellion at home, but has empowered her fearlessness and spite in the face of social ostracism.

Whiting's mention of Beaumont and Wentworth is an incidental observation in his text meant to illustrate only the impact of dissenting doctrine on domestic arrangements; the 'religious divisions of the time brought strife into families, and malice and uncharitableness amongst 
neighbors.' R. A. Knox, however, suggests that the liberty afforded women by the doctrines of 'enthusiastic' religion had a more crucial function: 'from the Montanist movement onwards, the history of enthusiasm is largely a history of female emancipation, and it is not a reassuring one. ${ }^{\prime 3}$ 'Enthusiasm,' that radical dimension of the dissenting tradition which tolerated, even esteemed, the prophet and the prophetess, ${ }^{4}$ gave voice to a disenfranchised class of men and women. '[I]f enthusiasm is a retort to oppression and repression, what it seeks to proclaim is man's triumphant mastery of an intolerant enviroment. ${ }^{5}$ The irony of Knox's analysis, from the perspective of our attention to the Vindication of Anne Wentworth, is that the mastery so earnestly claimed by the common man in his cry for religious and political liberty is also claimed by the common woman and often over the intolerable conditions right within her own home and community. Nearly thirty years before Anne Wentworth's separation from her husband, the dissenting preacher, Katherine Chidley, had demanded, 'I pray you tell me what authority [the] unbelieving husband hath over the conscience of his believing wife; it is true he hath authority over her in bodily and civil respects, but not to be a lord over her in conscience; and the like may be said of fathers and masters, and it is the same authority which the soveraigne hath over all his subjects and therefore it must needs reach to families. ${ }^{6}{ }^{C}$ Chidley's insistent query, in its echo of Luther's mandate that only Christ may be Lord and Master in the 'bedchamber' of the believer's conscience, signals the extent to which the dissenters' doctrines of free grace and the equality of believers pushed well beyond the church and the parliament, into the home. Keith Thomas writes that 'the growth of sectarianism certainly seemed likely to provoke direct conflicts of loyalty within the family."7

John Locke's Two Treatises on Government (1679) attacks the theory of patriarchy which creates an analogy between the government of the state and the family. The debate both reflected and engendered by his treatises is revealed in the comedy of the Restoration stage. In terms reminiscent of Katherine Chidley's earlier, notorious query, Lady Brute from Vanbrugh's The Provoked Wife (1697) contends that the argument for 'breakable contract' is 'good between the King and the people, why not between the husband and the wife?' Mary Astell (1706) turns the question with an even finer edge: 'Is it not then partial in men to the last degree to contend for a practice of that arbitrary dominion in their families which they abhor and exclaim against in the state? ... If all men are born free, how is it that all women are born slaves?'s

According to Michael Walzer in his classic theory of the origins of radical politics, the Calvinist God is the 'despot' behind the democratic urge expressed in such challenges to patriarchal hierarchy. 'A despot 
destroys the structure of intermediate powers and makes possible a politics based on individual interests.' The tyranny of the Calvinist God 'overthrew kingdoms at a stroke, sent churches into precipitous decline ... and bore the claims of no man. ${ }^{\prime 9}$ The familiar figure of John Bunyan's pilgrim embodies the spirit of Walzer's saint-in-exile, who, hearing the call of this jealous God, must abandon all old ties - family and fatherland - to pursue 'Life, life, eternal life.' An understanding of the part played by this 'gospel-seeker' in the non-conformist sects is central to understanding the case of Anne Wentworth. The Puritans celebrated the pilgrim/prophet more in theory than in practice. 'Freedom ... was not the Puritan purpose.'10 The seeker must, once freed from the bonds of false religion, return to the social order to take his place in the holy commonwealth and household government. But crucially - and this is the basis of Cromwell's redeemed regime - he does not return to the old order but enters a new society with a redeemed soul. But it is this latter call to return that the woman saint often found as onerous as the burden of her previous ignorance. 'Passive obedience,' writes Mary Chudleigh, 'you've transferred to us/ ... that antiquated doctrine you disown, /'Tis now your scorn and fit for us alone. ${ }^{\prime 11}$ As Thomas and others have suggested, the democratic implications of radical protestantism caused strife in the Puritan family.

Anne Wentworth was one of the last of the scores of female prophets in the seventeenth century; her gospel-seeking led her to proclaim her visions in The Revelation of Jesus Christ (1679) some twenty years after the Restoration had suppressed most such productions. Her case is notable for what it reveals about the cycles taken by the radical female zeal which had so burgeoned in the earlier part of the century. The celebrated role of the prophetess had virtually become extinct by $1700 .{ }^{12}$ In Anne Wentworth's Vindication we read of one woman's struggle to sustain the prophetic call and the liberty it gave her. Her testimony takes as its centerpiece a woman whose discoveries as pilgrim/prophet were not tolerated when she attempted to return to household government and church government. Yet crucially she refuses to abandon her calling only to submit to an old order. Bunyan speaks to the tyranny of household patriarchy when he recognizes this problem among the new converts of his own congregation; in 1666 he denounces 'mad-brained blasphemous husbands that are against the godly ... conversations of their wives. ${ }^{13}$

Cromwell's England, anxious as it was for signs of God's favor and direction, allowed prophetic utterance remarkable tolerance, even when it turned against the Protectorate. The prophet claims a domain outside traditional discourse and is protected by that very marginality. Again, by the time Wentworth is writing, this has changed. But her 
production of a Vindication suggests how very difficult it must have been for women to give up the privilege of this one biblically conferred freedom to speak. The prophetess is protected from the mockery made of the lady preacher because she claims no learning and even celebrates the frailty of her sex. What the female prophet discovered was that her role as despised woman gave her a paradoxical status. She may be weak in the world but it is with such that the God of the prophets prefers to dwell. There is then nothing appalling in the weak and unlearned seizing - often with a vengeance - the authority which gives them the gall to challenge existing hierarchy. If Bunyan found his own battle for the liberty to preach fought in the courts, Wentworth claims only the gift conferred upon women: her fight therefore is at home and in the local congregation. She pretends no rivalry with the rational domains of men. But she will not be silenced and she will not be relegated to madness. It is this position which anchors Wentworth's raging witness.

The form Wentworth's Vindication takes is important precisely because it is not a record of her prophesies and not a conventional spiritual autobiography, but rather an exposé of the very suppression of the radical spirit now recognized by historians. ${ }^{14}$ In her Vindication Wentworth subsumes the testimonial of the converted self to the cry for the liberty and the personal autonomy to practice her devotion in private and her prophesy in public. The account of her persecution does suggest, however, the liberating agency her prophesies became in the constitution of a new self, one constructed in protest against a world which in nearly every way deprived her of autonomy and expression. Her reluctance to surrender this agency is understandable. The briefest perusal of her work reveals the indignation and independence her sense of mission and divine protection grants her. I shall try here to give enough of the flavour of Wentworth's story to suggest perhaps why a C. E. Whiting, reading in the secure distance of early twentieth-century scholarship, would still find Anne Wentworth's indictment of her husband and her community not at all the record of a 'good' woman.

$\star \star * \star *$

Central to Anne Wentworth's Vindication is her justification for leaving her husband after sustaining 'severe persecutions for eighteen years. ${ }^{15}$ Central to Anne Wentworth's determination is the new marriage she finds with the Lord himself: 'My maker' she proclaims, 'is my husband. ${ }^{16}$ Her language is the language of revolution brought into the domestic realm: she has labored under 'the unspeakable tyrannies of an hard-hearted yoke-fellow' who has threatened both her spiritual 
and physical liberty with his brutalities. And she has been zealously persecuted and falsely accused by her former congregation of Baptists, who, she says, 'have called all their pretended church power to ... serve the wrath of my oppressors; and who, not being able truly to charge me with any sin ... that called for such a proceding, have declared me a heathen, and a publican for matters of conscience. ${ }^{17}$ She inveighs against the hypocrisy of the church: 'I have suffered as much Tiranny and Cruelty under formal profession of religion, as I could have amongst Turks, heathens, and Infidels.'

Wentworth claims that her detractors have falsely represented her as 'proud, passionate, revengeful, discontented and mad,' while they have represented her husband as scandalized and abandoned. The attacks on Wentworth's character, sex and sanity but above all on her prophesies provokes her Vindication. But her strategy is not to justify 'natural rights' in the face of such abuse but rather to announce publicly her vocation. She presents her case against her husband and her congregation through the exposure of their sin: St. Paul expressly forbids the preventing of prophesy within the church, and they have prevented her. Anne Wentworth proclaims her anointing from on high and proceeds to illustrate, with some detail and no little rage, her enemies' designs against the prophet of the Lord.

Chief among these designs to discredit her is the accusation of madness. Wentworth's retort to this familiar accusation is to design a fourpronged fork with which to pitch their slander back at them. First, she cites Solomon: 'as the preacher says, "oppression makes a wise man mad." ' Second, she reverses the charges: 'And yet I also judge it is the mistaken and rotten interest of my adversaries, not only to report but to believe me a person beside myself: for if I be found in a right mind, [then] how Mad must they be ... in their blind rage and fury against $m e$ and $m y$ testimony.' Third, prophets - from Jeremiah to Jesus himself - have always been called mad. And fourth, if she is mad then it is a fine thing to be so, for 'I do not write of myself: I am beside myself to God.'

This last of Anne Wentworth's defenses highlights again the question of how women participated in the discourse of Puritan theology and at the same time found the voice to protest against the intolerable circumstances of their oppression. Wentworth's response to her church's attack is to meet them with a new language of self-reclamation. However, the language of the Puritan can never be the language of natural rights. The paradox of Puritan testimony in general holds true to Wentworth's chronicle of her tribulation. The work holds its force precisely to the extent that its author conveys the depth of her selfabnegation. The assurance that God, who has been 'so many years 
emptying me from vessel to vessel, breaking me all to pieces in myself, and making me become as nothing before him - commanded me into this work when I was a thing that is not in my own eyes,' permits Wentworth's considerable self-advancement. ${ }^{18}$ This is the point one must grasp above all: the liberty won by the prophet, a liberty which puts a wedge between herself and all social context, requires an absolute submission to a supernatural ideal. Anne Wentworth aspires to the same principle of self-denial as St. Paul, who counts the loss of himself as nothing compared to the glories of knowing Christ. Yet like Paul who nevertheless lists his afflictions, his stripes and his narrow escapes, Wentworth makes clear that the barbarities against her defy natural law as well as the laws of Christ:

It would be very easie for me, from the great law of self-preservation, to justify my present absence from my earthly husband ... for as much as the natural constitution of my mind and body being both considered, he has ... done such things, as not only in the spirit of them will be counted a murdering ... but has long since really proved so, if God had not ... preserved me.

Her dilemma is that the Lord commands her to speak while her husband beats her into silence. It is, ironically, this - the 'natural' justification of her actions - which readers remember. 'Anne Wentworth, who accused her husband of beating her for her activities, maintained that her writings "were written solely against my own natural mind and will; that I often beg'd of God I might rather die than do it." '19 Her special insights were 'probably the result of an unhappy marriage, ${ }^{\prime 20}$ yet she remains one of the few female prophets who struggles 'consciously and with some success to assert her own independence. ${ }^{21}$

Wentworth's dilemma as prophet magnifies the general predicament of the female saint. Preaching in 1671, Jonathan Mitchell remarks, 'Woman is lastly ... as Homo (or one of mankinde) for God; but nextly and as Mulier (in her proper place and sex) for the man. ${ }^{22}$ Indeed, many popular treatises saw wife-beating as 'bettering' to women; while theological treatises condemned beating, they still advise female submission. William Gouge in his Domestical Duties (1634) argues that 'though an husband in regard of evil qualities may carry the image of the devil, yet in regard to his place and office, he beareth the image of God. ${ }^{23}$ It is on this point that Anne Wentworth stakes her claim to independence. She does not, strictly speaking, defend her natural right to protect her body (this, again, she will count as nothing while enumerating her 'stripes') but it is, at the same time, over her body as the vehicle of the Lord's prophesy that she resists and exposes her husband's tyranny. 
Wentworth's defense of 'negation' ('it is "not" that I want to defend myself') suggests how the appropriation of radical theology permitted her an eccentric escape from patriarchal force.

Thus Anne Wentworth's protest against her husband and her church is not for her life but for her work: and of course it is her work, her prophetic calling, which offers her a new life, insight, authority and power. In her relinquishing of her natural calling as wife, church member, and citizen she constructs a self driven by the myth of what Freud has called the 'family romance': her real family is in heaven; her Maker is her husband. Wentworth's anointing both severs her from the oppression of her worldly existence and offers the fantasy of privilege and protection. The price of counting the self 'a thing that was not' is no price at all:

I was forced to fly to preserve a life more precious than this natural one; and ... it was necessary to the peace of my soul, to absent myself from my earthly husband, in obedience to my heavenly bridegroom ... who called me ... to undertake and finish a work, which my earthly husband in a most cruel manner hindered me from performing, seizing and running away with my writings.

The writing of Anne Wentworth becomes, then, a creating of an autonomous authorized self. By stealing her writings, Wentworth's husband attempts to reclaim the house(hold) control he has lost because of her prophetic liberation. But Christ she repeats is the 'husband of her soul' though her proud earthly husband 'would control.' It is clear that her writings become the locus of the struggle because it is in them that her very being in the Lord is constituted. Her husband continues the violence against her body by destroying the 'body' of her work. Her recorded visions embody a new subjectivity, one now detached from the institution of household and church and constituted in the Lord, her heavenly bridegroom. If this submission to a transcendent authority for her own authorship seems doomed because it too participates in the symbols of patriarchy, we must understand that 'although there persists a romantic tendency to pit the individual against society in such a way as to suggest that ... [all] freedom consists of liberation from cultural forms ... radical movements are no less dependent upon organizing symbols than are the institutions under attack. ${ }^{24}$ Wentworth clearly uses the benign husbanding of the Lord as a means to circumvent her earthly husband's dominance. The symbol gives rise to thought: a cherished, internalized image of the ideal Father/husband is finally an internalized object. For, 'even when men and women have used the same symbols and rituals, they may have invested them with different meanings and different ways of meaning. ${ }^{25}$ For Anne Wentworth, 
the fantasy of a favored and favoring Lord enables her construction of a personal liberty which ultimately - in a remarkable reversal of the doctrines of domestic subjection - propels her into the public sphere. The domestic becomes by such a gesture political - just as Katherine Chidley had foretold in 1641.

Wentworth sets explicit terms for a return to her husband; they are the terms of liberty:

No more shall I return to be under the hands of the hard-hearted persecutor - unless he become a ... changed man ... and provided I have my just ... liberty to attend a more than ordinary call ... to publish the things which concern the peace of my soul and the whole nation.

It is in fact the public nature of Anne Wentworth's prophesies, the revelation that her 'oppression had a public ministry and meaning wrapt up in them,' that most enraged her enemies. The church members also steal her manuscripts and destroy them:

A more full account of [my ministry and witness] I am with all convenient speed preparing for the press, and had before made public, had not my Enemies hindered, by seizing and destroying my writings.

Wentworth mockingly challenges these censors to produce the book which they hold in custody: but 'no,' she cries, 'you dare not, ... you too well know it would demonstrate ... yourselves shameless lyars.' In crucial separation of herself from the congregation's history, she flings out, 'Pray consider, if one of your preachers should be silenced, you would presently cry out, persecution.' The female figure, as Hill pointed out, was the first to be silenced when the radical congregations, under the surveillance of the restored church, sought to demonstrate their orthodoxy. ${ }^{26}$ Given such persecution from within their own churches, it is clear why, well into the eighteenth century, reflective autobiographical forms would replace the prophetic spirit to channel women's vision: the constitution of the self offered by a mastery of language would sustain itself in the privacy of meditation, diary and conversion testimony. ${ }^{27}$

Anne Wentworth's Vindication is one of the last testimonies to fashion the prophet - one perfected through nearly twenty years of suffering to carry her vision. The only actual prophesy from her Vindication - that the whole nation will suffer if she is silenced - predicts the fate of a whole generation of women.

VERA J. CAMDEN

Kent State University 


\section{Notes}

1 C.E. Whiting, Studies in English Puritanism From the Restoration to the Revolution, 1660-1688 (New York: 1931), p. 123.

2 Whiting, p. 123.

3 R. A. Knox, Enthusiasm: A Chapter in the History of Religion (Oxford: 1950), p. 31.

4 Antonia Fraser, The Weaker Vessel (New York: 1975), pp. 256-58.

5 Knox, p. 35.

6 Katherine Chidley, The Justification of the Independent Churches of Christ, Being an Answer to Mr. Edwards his Booke (London: 1641), p. 26.

7 Keith Thomas, 'Women and the Civil War Sects,' in Crisis in Europe 1560-1660, ed. Trevor Aston (New York: 1965), p. 335.

8 Quoted in Lawrence Stone, The Family, Sex and Marriage in England 1500-1800 (New York: 1977), p. 240.

9 Michael Walzer, The Revolution of the Saints (Cambridge, Mass: 1982), p. 240.

10 Walzer, p. 197.

11 Quoted in Stone, p. 240.

12 Cf. Phyllis Mack, 'Women as Prophets during the English Civil War,' in The Origins of Anglo-American Radicalism, eds. Margaret and James Jacobs (London: 1984), p. 223.

13 Stone, p. 241.

14 Cf. Christopher Hill, The World Turned Upside Down: Radical Ideas During the English Revolution (New York: 1975); Margaret and James Jacobs, eds., Origins, intro.; Thomas, p. 99.

15 Anne Wentworth, A Vindication of Anne Wentworth tending to the better preparing of all People for the Larger Testimony which is making ready for Public View (London: 1677), p. 1.

16 Wentworth, p. 22.

17 Wentworth, p. 1.

18 Cf. Janet Todd 'Marketing the Self: Mary Carleton, Miss F. and Susan Gunning,' in Studies on Voltaire and the Eighteenth Century (Oxford: 1983), 95.

19 Mack, p. 220.

20 Rosemary Masek, 'Women in an Age of Transition 1485-1714,' in The Women of England - from Anglo-Saxon Times to the Present, ed. Barbara Kanner (New Haven: 1979), p. 162.

21 Mack, p. 225.

22 Quoted in Roger Thompson, Women in Stuart England and America (New York: 1974), p. 86. Cf. also Fraser, p. 264; Elizabeth Petroff, The Consolation of the Blessed (New York: 1979), p. 3. 
23 Quoted in Stone, p. 197.

24 Jacobs, p. 11.

25 Carolyn Walker Bynum, Stevan Harrell, Paula Richman, eds., Gender and Religion: On the Compexity of Symbols (Boston: 1986), p. 16.

26 Cf. Hill, p. 338.

27 Cf. Thompson, p. 94; Cynthia S. Pomerleau, 'The Emergence of Women's Autobiography in England' in Women's Autobiography: Essays in Criticism, ed., Estelle C. Jelinek (Bloomington: 1980), p. 78. 